\title{
Plasma Growth Hormone, Insulin, and Glucagon Responses to Arginine Infusion in Children and Adolescents with Idiopathic Short Stature, Isolated Growth Hormone Deficiency, Panhypopituitarism, and Anorexia Nervosa
}

\author{
PIERRE C. SIZONENKO, (56) ALEXANDER RABINOVITCH, PIERRE SCHNEIDER, LUC PAUNIER, \\ CLAES B. WOLLHEIM, AND GASTON ZAHND \\ Endocrinology Unit, Department of Pediatrics and Genetics; Institute of Clinical Biochemistry; and Foundation for \\ Medical Research; University of Geneva, Faculty of Medicine, Geneva, Switzerland
}

Extract

The effects of intravenous infusion of arginine $\left(20 \mathrm{~g} / \mathrm{m}^{2}\right)$ after an overnight fast on plasma immunoreactive growth hormone $(\mathrm{GH})$, insulin (IRI), and glucagon (IRG), and blood glucose were examined in five groups of children and adolescents: 10 normal individuals, 18 with idiopathic short stature, 6 with isolated growth hormone deficiency, 8 with panhypopituitarism, and 6 with anorexia nervosa. The mean fasting plasma $\mathbf{G H}$ concentration was significantly elevated in the group with anorexia nervosa $(P<0.05)$, and similar to the value for the normal group in all other groups. After arginine infusion, four- to sixfold increases of plasma GH were observed in the normal children, and similar increases were seen in those with idiopathic short stature as well as in those with anorexia nervosa; whereas, in the children with isolated growth hormone deficiency or panhypopituitarism, there was no significant increase in plasma GH. Fasting blood glucose concentrations were significantly lower than normal in subjects with isolated growth hormone deficiency $(P$ $<0.05)$, panhypopituitarism $(P<0.001)$, and anorexia nervosa $(P$ $<0.001$ ), whereas fasting plasma IRI and IRG concentrations were similar to the values in the normal group. Plasma IRI increased eightfold at the end of the 30 -min arginine infusion in the normal subjects; the increase was slightly but not significantly less in those with idiopathic short stature, and significantly less in those with isolated growth hormone deficiency $(P<\mathbf{0 . 0 5})$, panhypopituitarism $(P<\mathbf{0 . 0 0 1})$, and anorexia nervosa $(P<\mathbf{0 . 0 5})$. Arginine infusion resulted in two- to threefold increases of plasma IRG in the normal group, and similar increases were observed in all of the other groups tested. These results suggest that whereas pancreatic $\beta$ cell responsiveness may be deficient in children and adolescents with isolated growth hormone deficiency, panhypopituitarism, or anorexia nervosa, pancreatic $\alpha$ cell responsiveness, to arginine at least, appears to be intact under these conditions.

\section{Speculation}

Although plasma glucagon responses to arginine infusion were not less in subjects with hypopituitarism or anorexia nervosa than in normal subjects, relative hypoglucagonemia may have existed, since both basal and postarginine infusion plasma glucagon levels were not higher than normal in the presence of significantly lower blood glucose values. Thus, the present study does not exclude a deficient pancreatic $\alpha$ cell response to hypoglycemia. Alternatively, nonavailability of substrates for gluconeogenesis may have a more important influence than hormonal factors in the genesis of the hypoglycemia observed in these states.
The relationship between hypopituitarism and hypoglycemia has long been recognized (6) and is the subject of a recent review by Hopwood et al. (26). Among factors regulating the blood glucose concentration, pancreatic insulin, as well as glucagon (48), is recognized to have a prominent role. The influence of growth hormone on pancreatic $\beta$ cell function is well documented, and insulin responses to provocative stimuli have usually been reported

Table 1. Characteristics of subjects studied

\begin{tabular}{|c|c|c|c|}
\hline Subjects & $\begin{array}{l}\text { Age, } \\
\mathrm{yr} / \mathrm{mo}\end{array}$ & $\begin{array}{l}\text { Height, } \\
\mathrm{cm}\end{array}$ & $\begin{array}{l}\text { Weight, } \\
\text { kg }\end{array}$ \\
\hline \multicolumn{4}{|l|}{ Normal children } \\
\hline Mean $\pm \operatorname{SE}(10)^{1}$ & $13 / 3 \pm 1 / 10$ & $156 \pm 12$ & $43.4 \pm 4.9$ \\
\hline \multicolumn{4}{|c|}{ Idiopathic short stature } \\
\hline Mean $\pm \operatorname{SE}(18)$ & $10 / 5 \pm 1 / 10$ & $122 \pm 5$ & $24.8 \pm 2.3$ \\
\hline \multicolumn{4}{|c|}{$\begin{array}{l}\text { Isolated growth hormone } \\
\text { deficiency }\end{array}$} \\
\hline$C P$ & 12 & 130 & 37 \\
\hline$R P$ & $9 / 6$ & 120 & 22 \\
\hline$S S$ & 14 & 126 & 28 \\
\hline$G R$ & $14 / 6$ & 140 & 50 \\
\hline$L P$ & 14 & 138 & 36 \\
\hline DO & 15 & 133 & 29 \\
\hline Mean $\pm \operatorname{SE}(6)$ & $13 / 8 \pm 0 / 6$ & $131 \pm 7$ & $33.7 \pm 4$ \\
\hline \multicolumn{4}{|l|}{ Panhypopituitarism } \\
\hline$M G$ & 4 & 82 & 16 \\
\hline$B S$ & $4 / 6$ & 86 & 17 \\
\hline$G C$ & $5 / 6$ & 87 & 19 \\
\hline$R C$ & $5 / 6$ & 116 & 18.5 \\
\hline$D L$ & $9 / 6$ & 126 & 21 \\
\hline$B P$ & 10 & 127 & 32 \\
\hline$V D$ & 13 & 142 & 28 \\
\hline$F I$ & 15 & 145 & 40 \\
\hline Mean $\pm \operatorname{SE}(8)$ & $9 / 3 \pm 1 / 4$ & $114 \pm 9$ & $24 \pm 3$ \\
\hline \multicolumn{4}{|l|}{ Anorexia nervosa } \\
\hline$C I$ & $12 / 6$ & 164 & 37 \\
\hline$C N$ & $14 / 10$ & 168 & 38 \\
\hline$R E$ & 13 & 154 & 36 \\
\hline$S I$ & 15 & 157 & 32 \\
\hline$R T$ & 16 & 160 & 34 \\
\hline$P G$ & $13 / 3$ & 170 & 43 \\
\hline Mean $\pm \operatorname{SE}(6)$ & $14 / 4 \pm 0 / 6$ & $162 \pm 3$ & $36.7 \pm 1.5$ \\
\hline
\end{tabular}

${ }^{1}$ Mean \pm SE values for number of subjects indicated in parentheses. 
Table 2. Effect of arginine infusion on plasma growth hormone ${ }^{1}$

\begin{tabular}{|c|c|c|c|c|c|c|}
\hline Subjects & $-30 \mathrm{~min}$ & $0 \mathrm{~min}$ & $30 \mathrm{~min}$ & $60 \mathrm{~min}$ & $90 \mathrm{~min}$ & $120 \mathrm{~min}$ \\
\hline \multicolumn{7}{|l|}{ Normal children } \\
\hline Mean \pm SE $(10)$ & $2.8 \pm 1.0$ & $2.5 \pm 0.6$ & $10.7 \pm 3.8^{2}$ & $15.6 \pm 3.2^{3}$ & $11.6 \pm 3.6^{2}$ & $4.7 \pm 1.9$ \\
\hline Mean $\pm \operatorname{SE}(18)$ & $2.5 \pm 0.6$ & $2.5 \pm 0.7$ & $10.6 \pm 1.4$ & $14.3 \pm 2.3$ & $6.1 \pm 0.8$ & $4.7 \pm 0.9$ \\
\hline \multicolumn{7}{|c|}{ Isolated growth hormone deficiency } \\
\hline$C P$ & 1.9 & 0.4 & 1.5 & 0.9 & 0.6 & 0.4 \\
\hline$G R$ & 0.8 & 0.6 & 1.4 & 1.0 & 0.9 & 1.4 \\
\hline$L P$ & 2.0 & 1.1 & 0.4 & 1.6 & 1.7 & 2.1 \\
\hline$D O$ & 0.7 & 0.6 & 4.0 & 4.0 & 2.3 & 1.8 \\
\hline mean $\pm \mathrm{SE}(6)$ & $1.4 \pm 0.3$ & $1.2 \pm 0.4$ & $2.5 \pm 0.7$ & $2.5 \pm 0.7^{4}$ & $1.9 \pm 0.5^{5}$ & $1.6 \pm 0.4$ \\
\hline \multicolumn{7}{|l|}{ Panhypopituitarism } \\
\hline$M G$ & 1.0 & 0.7 & 1.0 & 3.4 & 0.8 & 0.7 \\
\hline$B P$ & 1.0 & 1.2 & 1.0 & 1.5 & 2.0 & 1.5 \\
\hline$V D$ & 3.2 & 2.7 & 3.7 & 5.2 & 4.3 & 3.4 \\
\hline$F I$ & 2.0 & 2.5 & 1.7 & 2.9 & 2.7 & 2.3 \\
\hline Mean $\pm \operatorname{SE}(8)$ & $2.1 \pm 0.5$ & $2.1 \pm 0.6$ & $2.0 \pm 0.5^{5}$ & $3.0 \pm 0.8^{4}$ & $2.6 \pm 0.6^{5}$ & $2.5 \pm 0.6$ \\
\hline \multicolumn{7}{|l|}{ Anorexia nervosa } \\
\hline$C I$ & 0.9 & $\bullet 1.4$ & 5.0 & 10.0 & 6.3 & 4.4 \\
\hline$C N$ & 13.6 & 11.7 & 9.2 & 18.8 & 36.2 & 21.4 \\
\hline$R E$ & 11.0 & 1.2 & 3.4 & 28.6 & 11.6 & 5.0 \\
\hline$S I$ & 5.8 & 4.4 & 7.0 & 3.2 & 34.2 & 10.6 \\
\hline$R T$ & 35.6 & 32.2 & 30.3 & 36.8 & 47.7 & 48.4 \\
\hline$P G$ & 3.5 & 3.4 & 14.0 & 18.5 & 8.1 & 8.4 \\
\hline Mean \pm SE $(6)$ & $11.7 \pm 5.1^{5}$ & $7.4 \pm 3.3$ & $11.5 \pm 4.1$ & $24.1=4.1^{5}$ & $24.0 \pm 7.2$ & $16.4 \pm 6.9$ \\
\hline
\end{tabular}

${ }^{1}$ Arginine $\left(20 \mathrm{~g} / \mathrm{m}^{2}\right)$ was infused over $30 \mathrm{~min}$ (from 0 to $\left.30 \mathrm{~min}\right)$ after an overnight fast, and mean $( \pm \mathrm{SE})$ plasma growth hormone concentrations (nanograms per milliliter) for numbers of subjects, indicated in parentheses, are shown at -30 to $120 \mathrm{~min}$.

${ }^{2} P<0.05$ versus preinfusion (mean of -30 and $0 \mathrm{~min}$ ) plasma growth hormone concentration.

${ }^{3} P<0.005$ versus preinfusion (mean of -30 and $0 \mathrm{~min}$ ) plasma growth hormone concentration.

${ }^{4} P<0.005$ versus mean plasma growth hormone concentrations at corresponding times in the normal group

${ }^{5} P<0.05$ versus mean plasma growth hormone concentrations at corresponding times in the normal group.

to be decreased in subjects with growth hormone deficiency $(8,13$, $18,39,41)$. Effects of growth hormone on pancreatic $\alpha$ cell function have only recently been reported $(5,20)$. The aim of the present experiments was to test pancreatic glucagon as well as insulin responsiveness in children and adolescents with deficiency of growth hormone secretion, and in others with idiopathic short stature or anorexia nervosa. Arginine infusion permitted the simultaneous assessment of plasma growth hormone, insulin, and glucagon secretory responses.

\section{MATERIALS AND METHODS}

\section{SUBJECTS}

The characteristics of the subjects studied are shown in Table 1. The first group consisted of 10 children and adolescents ( 4 females and 6 males, ages 6 years 9 months to 15 years) admitted to the surgery ward for minimal orthopedic trauma, but otherwise healthy, and these subjects served as "normal" control subjects. The second group consisted of 18 subjects ( 2 females and 16 males, ages 5 years 6 months to 15 years 5 months) with short stature (less than normal by 2 or more SD), and in whom no abnormality of pituitary, thyroid, or gonadal function was found. The third group consisted of 6 subjects ( 1 female and 5 males) with isolated $\mathrm{GH}$ deficiency. Plasma GH responses to insulin-induced hypoglycemia were severely blunted; plasma thyroxine levels were normal. Adrenocorticotropic hormone (ACTH) secretion was normal, as assessed indirectly after administration of metyrapone. Responses to synthetic gonadotropin-releasing hormone were normal in the 3 younger children with isolated GH deficiency, and gonadotropic secretion in the 3 older ones was considered normal, since pubertal development had begun. The fourth group consisted of 8 subjects ( 3 females and 5 males) with panhypopituitarism. All had GH, $\mathrm{TSH}$, and ACTH deficiencies, and gonadotropic deficiency was demonstrated in 2 of the 8 cases. Diabetes insipidus was present in the 4 cases which had a tumoral origin, whereas, in the 4 idiopathic cases, diabetes insipidus was absent. All the patients with panhypopituitarism were receiving dessicated thyroid gland powder and cortisone substitution $\left(25 \mathrm{mg} / \mathrm{m}^{2} / 24 \mathrm{hr}\right)$. None of the patients had received human growth hormone before or during the time of testing. The fifth group consisted of 6 female adolescents with anorexia nervosa; weight loss was between $35 \%$ and $38 \%$ below ideal body weight, and amenorrhea was present.

\section{METHODS}

All of the studies were performed after informed consent. After 3 days of a diet consisting of $55 \%$ carbohydrate, $17 \%$ fat, and $28 \%$ protein, and after an overnight fast, an intravenous infusion of isotonic saline was established in an antecubital vein. After a 30 -min equilibration period, arginine monohydrochloride $20 \mathrm{~g} / \mathrm{m}^{2}$ $(20 \mathrm{~g} / 100 \mathrm{ml}$, buffered to $\mathrm{pH}$ 7.4) was infused during $30 \mathrm{~min}(0-30$ min). Blood was collected in chilled heparinized plastic tubes containing EDTA and Trasylol at -30, 0, 30, 60, 90, and $120 \mathrm{~min}$. Plasma was stored at $-20^{\circ}$ until assayed. Blood glucose was 
estimated by the AutoAnalyzer ferricyanide method (7). Plasma growth hormone and insulin concentrations were determined by double-antibody radioimmunoassays $(24,30)$. Plasma immunoreactive glucagon was assayed (49) using an antipancreatic glucagon antiserum which purportedly measures true pancreatic glucagon (30-K antiserum, kindly provided by Dr. R. H. Unger, University of Texas South-Western Medical School, Dallas, Texas).

\section{RESULTS}

As indicated in Table 1, the mean age of the control population of normal children was around early adolescence; the ratio of mean weight to mean height was approximately at the 50th percentile. The mean age of the children with idiopathic short stature was 10.5 years. The height of this group corresponded to that of normal 7-year-old children, and they were slightly overweight (at 90th percentile for height). The mean age, height, and weight of the groups with idiopathic short stature and panhypopituitarism were very similar. The group with isolated growth hormone deficiency had an adolescent mean age, and was also overweight (90th percentile for height). The group with anorexia nervosa was significantly underweight for height, the latter being comparable with the normal control group.

\section{PLASMA IMMUNOREACTIVE GH (Table 2)}

In normal children, plasma $\mathrm{GH}$ rose significantly from a mean (of -30 and $0 \mathrm{~min}$ ) preinfusion fasting concentration of $2.7 \pm 0.7$ $\mathrm{ng} / \mathrm{ml}$ to a peak value of $15.6 \pm 3.2 \mathrm{ng} / \mathrm{ml}(P<0.005)$ at $30 \mathrm{~min}$ after the end of the arginine infusion $(60 \mathrm{~min})$. The $\mathrm{GH}$ response to arginine infusion was similar in children with idiopathic short stature, with a peak value of $14.3 \pm 2.3(P<0.001)$ at $60 \mathrm{~min}$. By contrast, in children with isolated growth hormone deficiency and in those with panhypopituitarism, plasma $\mathrm{GH}$ levels after arginine infusion did not rise significantly, and the concentrations attained were significantly lower than the values in the normal subjects at corresponding times. The mean fasting preinfusion plasma $\mathrm{GH}$ concentration in the group with anorexia nervosa $(9.6 \pm 4.2$ $\mathrm{ng} / \mathrm{ml})$ was significantly higher $(P<0.05)$ than the corresponding mean fasting value for the normal group $(2.7 \pm 0.7 \mathrm{ng} / \mathrm{ml})$, and at 30 min after arginine infusion, plasma $\mathrm{GH}$ rose to significantly higher levels $(P<0.05)$ in the group with anorexia nervosa $(24.1 \pm$ $4.1 \mathrm{ng} / \mathrm{ml})$ than in the normal subjects $(15.6 \pm 3.2 \mathrm{ng} / \mathrm{ml})$.

\section{BLOOD GLUCOSE (Table 3)}

The mean fasting preinfusion blood glucose concentrations were significantly lower in subjects with isolated growth hormone deficiency $(73 \pm 5 \mathrm{mg} / 100 \mathrm{ml}, P<0.05)$, panhypopituitarism $(60$ $\pm 6 \mathrm{mg} / 100 \mathrm{ml}, P<0.001)$, and anorexia nervosa $(63 \pm 3 \mathrm{mg} / 100$ $\mathrm{ml}, P<0.001)$, than in normal subjects $(83 \pm 2 \mathrm{mg} / 100 \mathrm{ml})$. Fasting blood glucose concentrations were not significantly below normal in subjects with idiopathic short stature $(83 \pm 2 \mathrm{mg} / 100$ $\mathrm{ml})$. There was a small but nonsignificant increase of blood glucose in the normal subjects at the end of the 30 -min arginine infusion (from $82 \pm 2$ to $95 \pm 3 \mathrm{mg} / 100 \mathrm{ml}$ ) followed by a return to preinfusion or slightly lower values $30 \mathrm{~min}$ after the end of the infusion. Similar changes were seen in all other groups.

Table 3. Effect of arginine infusion on blood glucose ${ }^{1}$

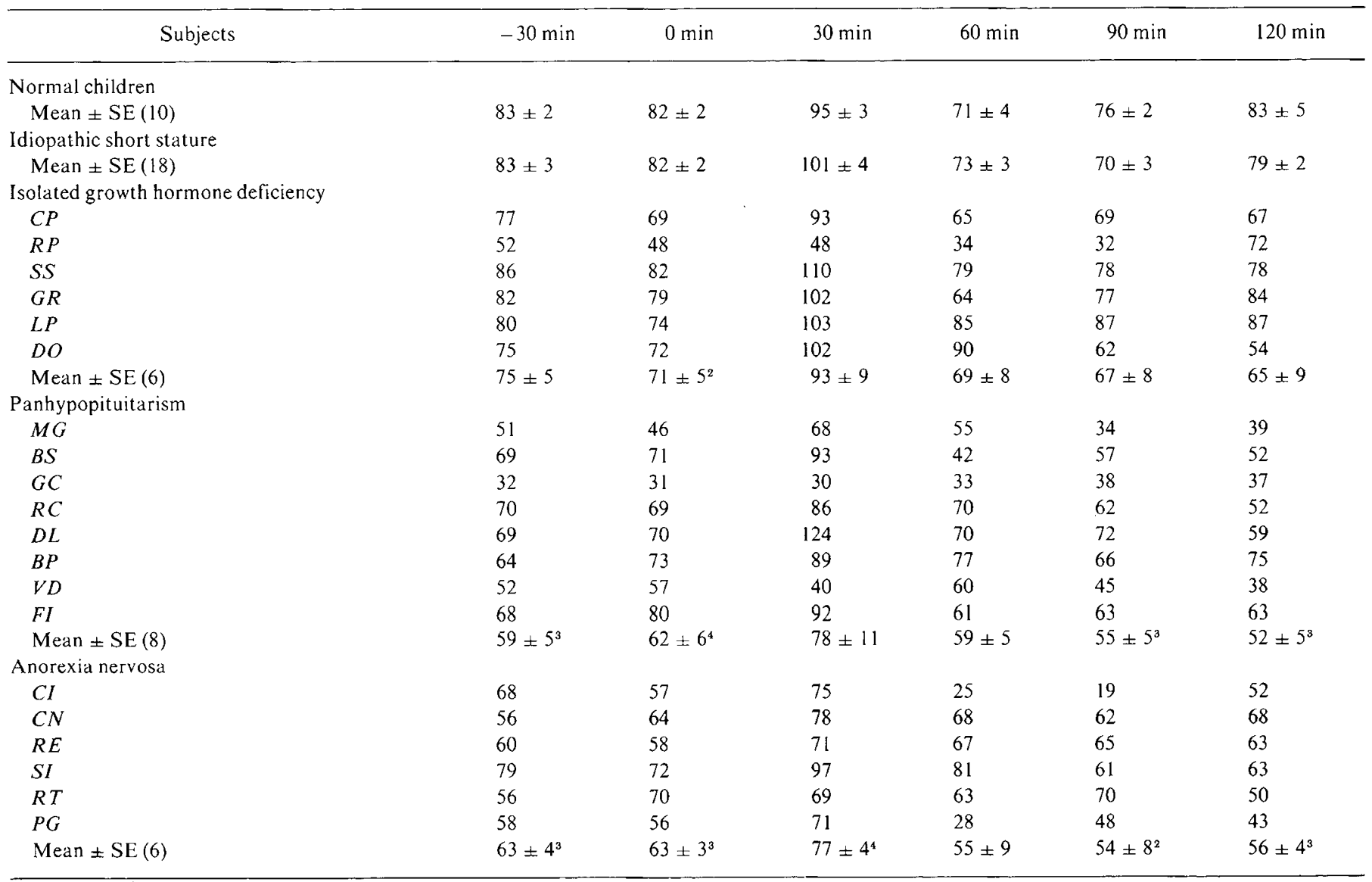

${ }^{1}$ Data are presented as in Table 2. Blood glucose concentrations at the times indicated are expressed in milligrams per $100 \mathrm{ml}$.

${ }^{2} P<0.05$ versus mean blood glucose concentration at corresponding times in the normal group.

${ }^{3} P<0.001$ versus mean blood glucose concentration at corresponding times in the normal group.

${ }^{4} P<0.005$ versus mean blood glucose concentration at corresponding times in the normal group. 
Table 4. Effect of arginine infusion on plasma insulin ${ }^{1}$

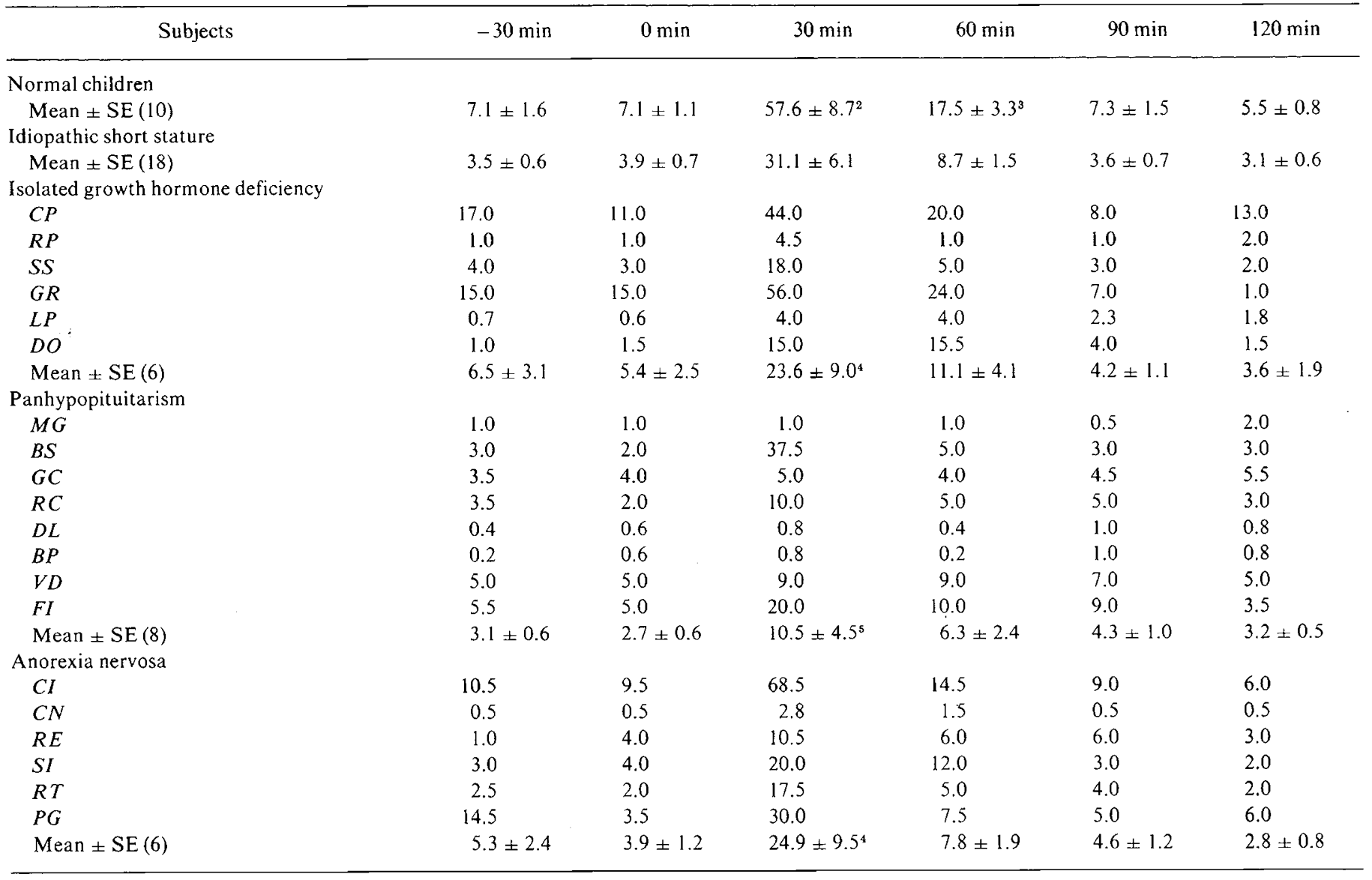

${ }^{1}$ Data are presented as in Table 2. Plasma insulin concentrations are expressed in microunits per milliliter.

${ }^{2} P<0.001$ versus preinfusion (mean of -30 and $0 \mathrm{~min}$ ), plasma insulin concentration.

${ }^{3} P<0.02$ versus preinfusion (mean of -30 and $0 \mathrm{~min}$ ), plasma insulin concentration.

${ }^{4} P<0.05$ versus mean plasma insulin concentrations at corresponding times in the normal group.

${ }^{5} P<0.001$ versus mean plasma insulin concentrations at corresponding times in the normal group.

\section{PLASMA IMMUNOREACTIVE INSULIN (IRI) (Table 4)}

Fasting plasma IRI levels were not significantly different in the various groups. In normal children, plasma IRI rose significantly from a mean preinfusion concentration of $7.1 \pm 1.2 \mu \mathrm{U} / \mathrm{ml}$ to $57.6 \pm 8.7$ at the end of a $30-$ min infusion of arginine $(P<0.001)$ and $17.5 \pm 3.3$ at $60 \mathrm{~min}(P<0.02)$. The IRI responses to the infusion of arginine were lower than normal in children with idiopathic short stature $(31.1 \pm 6.1 \mu \mathrm{U} / \mathrm{ml}$ at $30 \mathrm{~min})$; however, the difference from normal was not significant. By contrast, the increases of plasma IRI after arginine infusion were significantly smaller in the group of children with isolated growth hormone deficiency $(23.6 \pm 9.0 \mu \mathrm{U} / \mathrm{ml}$ at $30 \mathrm{~min} ; P<0.05)$, panhypopituitarism $(10.5 \pm 4.5 \mu \mathrm{U} / \mathrm{ml}$ at $30 \mathrm{~min}, P<0.001)$, and anorexia nervosa $(24.9 \pm 9.5 \mu \mathrm{U} / \mathrm{ml}$ at $30 \mathrm{~min}, P<0.05)$.

\section{PLASMA IMMUNOREACTIVE GLUCAGON (IRG) (TABLE 5)}

Fasting plasma IRG levels were not significantly different for the different groups. In normal children, plasma IRG increased significantly from a mean preinfusion concentration of $89 \pm 23$ $\mathrm{pg} / \mathrm{ml}$ to $231 \pm 60 \mathrm{pg} / \mathrm{ml}$ at the end of the $30-\mathrm{min}$ infusion of arginine $(P<0.005)$ and $181 \pm 39 \mathrm{pg} / \mathrm{ml}$ at $60 \mathrm{~min}(P<0.02)$. The plasma IRG response to arginine infusion was not significantly less than normal in the group with idiopathic short stature. In both groups with growth hormone deficiency (isolated $\mathrm{GH}$ deficiency and panhypopituitarism) and in the group with anorexia nervosa, plasma IRG responses to arginine were slightly higher than in normal children; however, the differences were not significant.
DISCUSSION

In clinical investigation, the intravenous infusion of arginine has become a useful tool for stimulating growth hormone $(15,42)$, insulin (12), and glucagon secretion $(3,48)$, and has been widely used for diagnosis of growth hormone deficiency. Similarly, in the present study, plasma GH responses to arginine in children and adolescents with idiopathic short stature were not significantly different from those observed in normal control subjects, but were severely blunted in individuals with either isolated growth hormone deficiency or panhypopituitarism. Thereby, the arginine infusion test has been validated as a diagnostic tool.

In anorexia nervosa, basal plasma $\mathrm{GH}$ levels have been reported to be either high $(9,21,29,31,37)$ or low (14), and plasma $\mathrm{GH}$ levels have been reported to be low in marasmus $(4,16,17)$ or in maternal deprivation (45). On the contrary, they were found to be high in kwashiork or $(4,16,17,36,44)$. In two of our six cases with anorexia nervosa, plasma $\mathrm{GH}$ was clearly higher than normal, both in the fasting state, and at 60 and 90 min after arginine infusion.

Both stimulatory $(8,13,35,39,40,43,46,51)$ and inhibitory (1) effects of growth hormone on insulin secretion have been reported. In children with growth hormone deficiency, plasma IRI responses to arginine $(8,41,46,50,51)$ or to glucose $(47)$ have been reported as either normal or decreased. The mean plasma IRI responses to arginine in the groups with isolated growth hormone deficiency and panhypopituitarism were significantly decreased; however, there was a great individual variation, some subjects exhibiting a normal insulin response. The latter was usually associated with a 
normal basal (preinfusion) plasma insulin level, in turn possibly related to the more normal weight to height ratio in these individuals (26). An age-dependent response of IRI to different stimuli in hypopituitarism has also been shown (26); however, this does not appear to account for the individual differences observed in the present study. It is well recognized that the blood glucose level can modulate the insulin secretory response to different agents, including arginine $(10,19,34)$. Indeed, the poorest plasma IRI responses to arginine were observed in the groups (i.e., anorexia nervosa, panhypopituitarism, and isolated growth hormone deficiency) which has blood glucose concentrations (fasting and postarginine infusion) lower than normal; however, the individual differences do not appear to be explained on this basis. Hypoinsulinemia has also been reported in chronic starvation (11, 17,23 ) and prolonged fasting has been reported to blunt the insulin secretory response to arginine (2). Similarly, in the present study, the mean plasma IRI response to arginine in the six adolescent females with anorexia nervosa was significantly less than in the normal group. Also, in agreement with several reports $(22,25,27)$, the group of children with idiopathic short stature had decreased plasma IRI levels, both before and after arginine, although the differences from normal were not significant.

A diminished plasma IRG response to arginine in growth hormone deficient adults was first reported by Goldfine et al. (20, 33). More recently, Blackard et al. (5) found normal plasma IRG responses to arginine in adult subjects with hypopituitarism before and after growth hormone administration. Normal glucagon responses were observed (28) in children with idiopathic short stature. In the present study, children and adolescents with isolated growth hormone deficiency or panhypopituitarism had plasma IRG levels similar to normal in the fasting state, and the plasma IRG responses to arginine were also similar to those observed in the normal group. Thus, prolonged pituitary GH deficiency does not appear to influence glucagon secretory responses, whereas insulin secretion may be clearly depressed. In prolonged fasting ( 2 , 32,38 ), plasma IRG has been shown to rise until the third day of fasting, and thereafter, to decrease to a level maintained at or slightly above postabsorptive levels (38). In our cases of anorexia nervosa, still largely underweight, fasting plasma IRG was not increased, and IRG responses to arginine were normal or slightly augmented as reported previously in starvation (2).

The present findings of fasting plasma IRG levels in the normal range, together with a blood glucose level significantly lower than normal in the groups with anorexia nervosa, isolated growth hormone deficiency, and panhypopituitarism suggest that the glucagon response to hypoglycemia may be relatively deficient in these conditions. However, plasma glucagon as well as blood sugar increments after arginine infusion were normal or slightly greater than normal. Therefore, whether the hypoglycemia associated with anorexia nervosa or with hypopituitarism may be attributed to deficient glucagon secretion, cannot be answered definitively from the present data.

\section{SUMMARY}

The effects of intravenous infusion of arginine $\left(20 \mathrm{~g} / \mathrm{m}^{2}\right)$ on plasma immunoreactive $\mathrm{GH}$, IRI, IRG, and blood glucose were examined in 10 normal children and adolescents, 18 with idi-

Table 5. Effect of arginine infusion on plasma immunoreactive glucagon $(I R G)^{1}$

\begin{tabular}{|c|c|c|c|c|c|c|}
\hline Subjects & $-30 \mathrm{~min}$ & $0 \mathrm{~min}$ & $+30 \mathrm{~min}$ & $+60 \cdot \min$ & $+90 \min$ & $+120 \mathrm{~min}$ \\
\hline \multicolumn{7}{|l|}{ Normal children } \\
\hline Mean \pm SE $(10)$ & $102 \pm 40$ & $86 \pm 23$ & $231 \pm 60^{2}$ & $181 \pm 39^{3}$ & $107 \pm 28$ & $74 \pm 22$ \\
\hline \multicolumn{7}{|l|}{ Idiopathic short stature } \\
\hline Mean \pm SE $(18)$ & $118 \pm 33$ & $89 \pm 30$ & $182 \pm 39$ & $134 \pm 29$ & $101 \pm 25$ & $104 \pm 25$ \\
\hline \multicolumn{7}{|c|}{ Isolated growth hormone deficiency } \\
\hline$C P$ & 265 & 175 & 240 & 255 & 150 & 180 \\
\hline$R P$ & 50 & 210 & 600 & 280 & 250 & 310 \\
\hline$S S$ & 45 & 35 & 70 & 55 & 20 & 40 \\
\hline$G R$ & 45 & 10 & 170 & 120 & 40 & 40 \\
\hline$L P$ & 60 & 40 & 280 & 250 & 100 & 40 \\
\hline$D O$ & 105 & 105 & 390 & 65 & 165 & 100 \\
\hline Mean + SE (6) & $96 \pm 36$ & $102 \pm 31$ & $291 \pm 76$ & $171 \pm 42$ & $121 \pm 35$ & $118 \pm 45$ \\
\hline \multicolumn{7}{|l|}{ Panhypopituitarism } \\
\hline$M G$ & 135 & 130 & 325 & 155 & 145 & 140 \\
\hline$B S$ & 200 & 160 & 760 & 330 & 275 & 130 \\
\hline$G C$ & 130 & 132 & 380 & 410 & 325 & 330 \\
\hline$R C$ & 20 & 40 & 240 & 230 & 110 & 40 \\
\hline$D L$ & 20 & 30 & 220 & 125 & 90 & 35 \\
\hline$B P$ & 20 & 25 & 255 & 145 & 62 & 65 \\
\hline$V D$ & 155 & 155 & 185 & 175 & 170 & 175 \\
\hline$F I$ & 80 & 45 & 195 & 180 & 145 & 92 \\
\hline Mean \pm SE $(8)$ & $95 \pm 25$ & $90 \pm 21$ & $320 \pm 67$ & $219 \pm 36$ & $165 \pm 32$ & $125 \pm 34$ \\
\hline \multicolumn{7}{|l|}{ Anorexia nervosa } \\
\hline$C I$ & 195 & 215 & 300 & 270 & 220 & 265 \\
\hline$C N$ & 45 & 15 & 160 & 130 & 95 & 75 \\
\hline$R E$ & 30 & 30 & 230 & 970 & 560 & 470 \\
\hline$S I$ & 60 & 70 & 240 & 285 & 170 & 150 \\
\hline$R T$ & 75 & 50 & 195 & 110 & 125 & 90 \\
\hline$P G$ & 30 & 35 & 75 & 85 & 120 & 30 \\
\hline Mean $\pm \mathrm{SE}(6)$ & $72 \pm 26$ & $69 \pm 30$ & $200 \pm 32$ & $308 \pm 137$ & $215 \pm 71$ & $180 \pm 70$ \\
\hline
\end{tabular}

${ }^{1}$ Data are presented as in Table 2. Plasma glucagon concentrations are expressed in picograms per milliliter.

${ }^{2} P<0.005$ versus preinfusion (mean of -30 and $0 \mathrm{~min}$ ) plasma glucagon concentration.

${ }^{3} P<0.02$ versus preinfusion (mean of -30 and $0 \mathrm{~min}$ ) plasma glucagon concentration. 
opathic short stature, 6 with isolated growth hormone deficiency, 8 with panhypopituitarism, and 6 with anorexia nervosa.

In the group with idiopathic short stature, fasting, as well as postarginine infusion plasma GH, IRI, IRG, and blood glucose concentrations, were similar to the values in the normal group. Plasma GH response to arginine was essentially absent in the groups with isolated $\mathrm{GH}$ deficiency and panhypopituitarism, but intact in anorexia nervosa; however, in all three groups fasting blood glucose concentrations were significantly diminished and plasma IRI responses to arginine were significantly decreased. Plasma IRG, both fasting and after arginine infusion, was not significantly different from normal in all of the groups studied.

\section{REFERENCES AND NOTES}

1. Adamson, U., and Cerasi, E.: Acute suppressive effect of human growth hormone on basal insulin secretion in man. Acta Endocrinol., 79: 474 (1973).

2. Aguilar-Parada, E., Eisentraut, A. M., and Unger, R. H.: Effects of starvation on plasma pancreatic glucagon in normal man. Diabetes, 18: 717 (1969).

3. Assan, R., Rosselin, G., and Dolais, J.: Effects sur la glucagonémie des perfusions et ingestions d'acides aminés. J. Ann. Diabétol. Hôtel-Dieu, 7: 25 (1967).

4. Beas, F., Contreras, I., Macchioni, A., and Arenas, S.: Plasma growth hormone levels in severe infantile malnutrition. J. Pediat., 77: 721 (1970)

5. Blackard, W. G., Andrews, S. S., and Lazarus, E. J.: Effect of growth hormone deficiency on glucagon secretion. Proc. Exp. Biol. Med., 143: 1042 (1973)

6. Brasel, J. A., Wright, J. C., Wilkins, L., and Blizzard, R. M.: An evaluation of seventy-five patients with hypopituitarism beginning in childhood. Am. J. Med., 38: 484 (1965).

7. Brown M. E.: Ultra-sugar determinations using 2,9-dimethyl-1,10-phenanthroline hydrochloride (neocupreine). Diabetes, 10:60 (1961).

8. Costin, G., Kogut, M. D., and Frasier, S. D.: Effect of low-dose human growth hormone on carbohydrate metabolism in children with hypopituitarism. J. Pediat., 80: 796 (1972).

9. Danowski, T. S., Livstone, E., Gonzales, A. R., Jung, Y., and Khurana, R. C.: Fractional and partial hypopituitarism in anorexia nervosa. Hormones, 3: 105 (1972).

10. Effendic, S., Cerasi, E., and Luft, R.: Role of glucose in arginine-induced insulin release in man. Metabolism, 20: 568 (1971).

11. Felig, P., Marliss, E. B., and Cahill, G. F., Jr.: Metabolic response to human growth hormone during prolonged starvation. J. Clin. Invest., 50: 411 (1971).

12. Floyd, J. C., Fajans, S. S., Conn, J. W., Knopf, R. F., and Rull, J.: Stimulation of insulin secretion by amino acids. J. Clin. Invest., 45: 1487 (1966).

13. Frohmann, L. A., McGillivray, M. H., and Aceto, T., Jr.: Acute effects of human growth hormone on insulin secretion and glucose utilization in normal and growth deficient subjects. J. Clin. Endocrinol., 27: 561 (1967)

14. Girard, J., Baumann, J. B., Stahl, M., Nars, P. W., Buehler, U., and Wick, H.: Experience with insulin-induced hypoglycemia as a provocative test for growth hormone and cortisol secretion for children. Hormones, 2: 338 (1971).

15. Glick, S. M., Roth, J., Yalow, R. S., and Berson, S. A.: The regulation of growth hormone secretion. Recent Progr. Hormone Res., 24: 241 (1965).

16. Godard, C., and Zahnd, G. R.: Growth hormone in severe infantile malnutrition. I. Plasma growth hormone response to hypoglycemia. Helv. Paediat. Acta, 26: $266(1971)$.

17. Godard, C., and Zahnd, G. R.: Growth hormone and insulin in severe infantile malnutrition. II. Plasma insulin and growth hormone during intravenous glucose tolerance test. Helv. Paediat. Acta, 26: 276 (1971)

18. Gold, H., Spector, S., Samaan, N. A., and Pearson, O. F.: Effect of growth hormone on the carbohydrate metabolism in hypopituitary dwarfs. Metabolism, 17: 74 (1968).

19. Goldfine, I. D., Cerasi, E., and Luft, R.: Glucagon stimulation of insulin release in man: Inhibition during hypoglycemia. J. Clin. Endocrinol. Metab., 35: 312 (1972).

20. Goldfine, I. D., Kirsteins, L., and Lawrence, A. M.: Excessive glucagon responses to arginine in active acromegaly. Hormone Metab. Res., 4: 97 (1972).

21. Green, O. C., Dyck, P., v., and Boschman, M. M.: Pituitary insufficiency in anorexia nervosa. J. Pediat., 72: 572 (1968).

22. Grunt, J. A., Crigler, J. F., Jr., Slone, D., and Soeldner, J. S.: Changes in serum insulin blood sugar and free fatty acid levels four hours after administration of human growth hormone to fasting children with short stature. Yale J. Biol. Med., 40: 68 (1967).

23. Hadden D. R.: Glucose, free fatty acid and insulin interrelations in kwashiorkor and marasmus. Lancet, i: 589 (1967)

24. Hales, C. N., and Randle, P. J.: Immunoassay of insulin with insulin antibody precipitate. Biochem. J., 88: 137 (1963).

25. Hilman, D. A., and Colle, E.: Plasma growth hormone and insulin response in short children. Am. J. Dis. Child., 117: 636 (1969)

26. Hopwood, N. J., Forsman, P. J., Kenny, F. M., and Drash, A.: The relationship between hypopituitarism and hypoglycemia. Advances in Human Growth Hormone Research p. 819 (United States Department of Health, Education and Weifare, Publication No. (NIH) 74-612, 1974).

27. Karp, M., Laron, Z., and Doron, M.: Insulin secretions in children with constitutional familial short stature. J. Pediat., 83: 241 (1973).
28. Josefsberg, Z., Laron, Z., Doron, M., Karp, M., and Weisman, I.: Plasma glucagon response to arginine infusion in children and adolescents with constitutional (familial) short stature. J. Pediat., 85: 437 (1974).

29. Krieger, I., and Melinger, R. C.: Pituitary function in the deprivation syndrome. J. Pediat., 79: 216 (1971).

30. Lambert, A. E., Luyckx, A., and Zahnd, G. R.: Improvement of human growth hormone immunoassay using 125 I. Proc. Soc. Exp. Biol. Med., 126: 405 (1967).

31. Landon, J., Greenwood, F. C., and Stampt, C. B.: The plasma sugar, free fatty acid cortisol and growth hormone responses to insulin and the comparison of this procedure with other tests of pituitary and adrenal function. II. In patients with hypothalamic or pituitary dysfunction or anorexia nervosa. J. Clin. Invest., 45: 437 (1966)

32. Lawrence A. M.: Radioimmunoassayable glucagon levels in man: Effects of starvation, hypoglycemia, and glucose administration. Proc. Natl. Acad. Sci. U. S. A., 55: 316 (1966).

33. Lawrence, A. M.: In P. J. Lefebvre and R. H. Unger: Glucagon, p. 259 (Pergamon Press, Oxford, 1972).

34. Levin, S. R., Karam, J. H., Hane, S., Grodsky, G. M., and Forsham, P. H. Enhancement of arginine-induced insulin secretion in man by prior administration of glucose. Diabetes, 20: 171 (1971).

35. Luft, R., and Cerasi, E.: Effect of human growth hormone on insulin production in panhypopituitarism. Lancet, $i i: 124$ (1964).

36. Lunn, P. G., Whitehead, R. G., Hay, R. W., and Baker, B. A.: Progressive changes in serum cortisol, insulin and growth hormone concentrations and their relationship to the distorted amino acid pattern during the development of kwashiorkor. Brit. J. Nutr., 29: 399 (1973).

37. Marks, V., Howorth, N., and Greenwood, F. C.: Plasma growth hormone levels in chronic starvation in man. Nature, 208: 686 (1965).

38. Marliss, E. B., Aoki, T. T., Unger, R. H., Soledner, J. S., and Cahill, G. F., Jr. Glucagon levels and metabolic effects in fasting man. J. Clin. Invest., 49: 2256 (1970).

39. Merimee, T. J., Burgess, J. A., and Rabinowitz, D.: Influence of growth hormone on insulin secretion: Studies of growth hormone deficient subjects. Diabetes, 16: 478 (1967)

40. Merimee, T. J., Felig, P., Marliss, E. B., Fineberg, S. E., and Cahill, G. F., Jr.: Glucose and lipid homeostasis in the absence of human growth hormone. J. Clin. Invèst., 50: 574 (1971).

41. Merimee, T. J., Hall, J. D., Rimoin, D. L., and McKusik, V. A.: A metabolic and hormonal basis for classifying ateliotic dwarfs. Lancet, $i$ : 963 (1969).

42. Merimee, T. J., Lillicrap, D. A., and Rabinowitz, D.: Effect of arginine on serum levels of human growth hormone. Lancet, ii: 668 (1965).

43. Merimee, T. J., Rabinowitz, D., Hall, J., Rimoin, D. L., and McKusik, V. A.: Isolated human growth hormone deficiency. IV. The response of sexua ateliotic dwarfs to exogenous growth hormone. Metabolism, 17: 1012 (1968).

44. Pimstone, B. L., Wittmann, W., Hansen, J. D. L., and Murray, P.: Growth hormone and kwashiorkor: Role of protein in growth hormone homeostasis. Lancet, ii: 779 (1966).

45. Poweil, G. F., Brasel, J. A., Raiti, S., and Blizzard, R. M.: Emotional deprivation and growth retardation simulating idiopathic hypopituitarism. 11. Endocrinologic evaluation of the syndrome. New Engl. J. Med., 276: 1279 (1967).

46. Root, A. W., Bongiovanni, A. M., and Eberlein, W. R.: Diagnosis and management of growth retardation with special reference to the problem of hypopituitarism. J. Pediat., 78: 737 (1971).

47. Underwood, L. E., Van den Brande, J. L., Antony, G. J., Voina, S. J., and Van Wyk, J. J.: Islet cell function and glucose homeostasis in hypopituitarism: Synergism between growt hormone and cortisone. J. Pediat., 82: 28 (1973).

48. Unger, R. H., Aguilar-Parada, E., Muller, W. A., and Eisentraut, A. M.: Studies of pancreatic alpha-cell function in normal and diabetic subjects. J. Clin. Invest., 49: 837 (1970).

49. Unger, R. H., Ketterer, H., Dupre, S., and Eisentraut, A. M.: The effects of secretin, pancreozym and gastrin on insulin and glucagon secretion in anesthesized dogs. J. Clin. Invest., 46: 630 (1967).

50. Youlton, R., Kaplan, S. L., and Grumbach, M. M.: Growth and growth hormone. IV. Limitations of the growth hormone response to insulin and arginine and of the immunoreactive insulin response to arginine in the assessment of growth hormone deficiency in children. Pediatrics, 43: 989 (1969)

51. Zuppinger, K. A., and Joss, E. E.: Influence of long term growth hormone therapy on glucose tolerance and insulin secretion. Acta Paediat. Scand., 60 678 (1971)

52. We gratefully acknowledge the technical assistance of Mrs. M. Wyss, Mrs. L. Cavillier, and Mr. D. Sourisseau, and the secretarial work of Mrs. C. Campana and Mr. D. Furrer. We express our thanks to Drs. A. E. Renold, M. D. Kogut, and $\mathrm{P}$. E. Ferrier for their critical suggestions and advice when preparing the manuscript. We are thankful to the Laboratoire VeyronFroment (France), for making arginine monochloride available to us.

53. This paper was presented in part at the Annual Meeting of the European Society for Clinical Investigation, Rotterdam, The Netherlands, April 24-26, 1974.

54. This research was supported by the Swiss National Fund for Scientific Research, Grants nos. 3.676.71, 3.0910.73, and 3.1060.73

55. Dr. Alexander Rabinovitch is recipient of a Centennial Fellowship of the Medical Research Council of Canada.

56. Requests for reprints should be addressed to: P. C. Sizonenko, M.D., Clinique Universitaire de Pédiatrie, 30, Bd. de la Cluse, 1211 Geneva 4 (Switzerland) 57. Accepted for publication May 19, 1975. 